\title{
Problem-solving step analysis for increasing tire static balance levels: a case study
}

\author{
Tubagus Hendri Febriana ${ }^{1 *}$, Hendi Herlambang ${ }^{1}$, Hernadewita $^{1}$, Hasbullah $^{1}$, Abdul Halim ${ }^{2}$ \\ ${ }^{1}$ Department of Magister Industrial Engineering, Universitas Mercu Buana, Jl. Raya Meruya Selatan No. 1 Jakarta 11650, Indonesia \\ ${ }_{2}^{2}$ PT. Sumi Rubber Indonesia, Jl. Letjen M.T. Haryono, Jatinegara, Jakarta Timur, Jakarta 13330, Indonesia
}

\begin{tabular}{l} 
ARTICLE INFORMATION \\
\hline Article history: \\
Received: May 12, 2021 \\
Revised: June 13, 2021 \\
Accepted: June 29, 2021 \\
\hline
\end{tabular}

Keywords:

Root cause analysis

Fault tree analysis

Failure mode and effect analysis Tire

\section{A B S T R A C T}

\begin{abstract}
One of the company's efforts in implementing the commitment to customer satisfaction is carried out through continuous improvement activities. All indicators are evaluated to determine the level of quality stability against process variations that will impact noncompliance with predetermined product specifications. One of the quality problems found in the tire manufacture industry is the outpercentage of tire uniformity, which suddenly increases, one of which is the value of static balance. This study analyses the process variation factors that occur to take corrective and preventive actions through a series of Root Cause Analysis (RCA), Fault Tree Analysis (FTA), and Failure Mode and Effect Analysis (FMEA). Refers to the analysis result, it was found that there was a problem with the rubber film gauge variation at the manufacturing step of the steel breaker, one of the material components in the tire construction. Two main factors cause rubber film thickness variation: rubber sticky with roll calendar, Radial Run Out (RRO) Roll Calendar out standard, and viscosity compound variation with 12 root problems found. The results of the improvements that have been made can effectively improve rubber film thickness variation, increase the Cpk level of steel breaker material from 0.82 to 1.91 and reduce the out percentage ratio of static balance by $54.65 \%$.
\end{abstract}

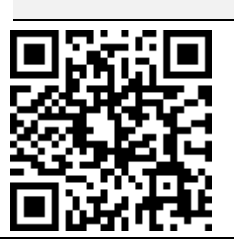

This is an open-access article under the CC-BY-NC-SA license.

\footnotetext{
*Corresponding Author

Tubagus Hendri Febriana

E-mail: tubagus.hendri77@gmail.com
}

\section{INTRODUCTION}

In the manufacturing process, productivity and quality stability sometimes become the main problems faced by companies. Product quality measurement and improvement are important aspects of the production process [1] to maintain company performance. Continuous improvement is an effort to develop and improve products, services, or processes carried out continuously to get better conditions. This activity can produce the best solution to various problems faced so that everything will continue to develop better over time. Problem-solving has become a standard method many companies use to solve issues that significantly impact their business processes.

One of the issues found in a tire manufacturing company was a surge in scrap caused by an increase in the standard static balance for two consecutive months. Static balance is performed in one area where weight loss is added to the 
wheel's opposite side. In tire manufacturing companies, static balance measurement automatically uses sensors and continues with dynamic balance measurement when the tire rotates [2]. Static imbalances will cause discomfort during use, damage to wheel rims and other vehicle parts due to vibrations, and impaired stability while driving [3]. In this case, a Problem-solving step analysis was carried out using the RCA, FTA, and FMEA methods to find the root of the problem faced by determining the steps for improvement as a method in risk management [4], [5].

RCA technique in the problem-solving process helps teams to acknowledge the causal effect relationship of failures to eliminate or reduce the potency of repetition in the future [6]. One of the methods that complement the RCA process is FTA [7], [8], which is frequently used for reliability analysis in critical systems [9], [10], and [11]. Other approaches that can be used to prevent product damage due to system or process failures before the problem occurs can be made through FMEA [12], [13] to improve the quality and analysis of product inconsistency [14]. FMEA is a bottom-up method that is less structured and requires more expert knowledge than FTA, which is a top-down method [15], and this tool has become one of the most commonly used in industries [16], [17].

In this study, FTA and FMEA are used for performing failure analysis on the critical function level failure modes to define countermeasure action [18], [19]. Fault Tree Analysis is a structured diagram analysis that identifies elements that can cause system failure to analyze the impact of emerging risks [4], [20] and determines the specific level of error based on deductive logic [21]. This method is top-down assuming failure or loss of the peak event (top event) [22]. Detailing the causes of a top event to a basic failure (root cause) to analyze the causative factors of problems that occur that lead to undesirable events based on the construction of fault tree diagrams [7]. FTA is a graphical model that uses two main symbols called events and gates [23] that describes relevant failures and combinations of errors that may occur within the system and how these failures interact to cause overall system failures possibly [20]. With this FTA method, it will be possible to know the failures that cause the undesired event and the probability of the undesired event happened. Finding the causes of undesired events is qualitative analysis, and looking for probabilities is quantitative analysis. By conducting quantitative analysis, it can be seen which part of the system failed. Then preventive actions need to be taken based on existing failures to eliminate the same incident's potency not happening again in the future.

FMEA is a systematic and structured approach to define, identify, and eliminate all potential failure modes and their effects [5], [24], [25]. FMEA is an effective tool and one of the most commonly used in different industries [19], [26], [27] to identify sources and root causes of quality problems and then prepare countermeasures and priorities actions that need to be addressed, starting with the highest priority ones. FMEA is also documenting current knowledge and actions about the risks of continuous improvement failures. FMEA is divided into two types:

1. Design FMEA is a tool used to ensure that potential failure modes, cause, and effect have been considered concerning product characteristics to be made by the design engineer Team (designer).

2. Process FMEA is a tool used to ensure that potential failure modes, causes, and consequences have been considered according to the characteristics of the process by the process engineer team. This type of research will be carried out in this study to analyze the failure factors in each process.

There are seven basic steps in FMEA [28]. FMEA is conducted to determine the potential failures and possible levels of risk in the company's operational activities [29]. Three factors determine the level of risk: $\mathrm{S}$ (severity), $\mathrm{O}$ (occurrence), and D (detection), where for the assessment standard, each has a score of 1-10. The level of failure risk can be determined from the RPN (Risk Priority Number). It is calculated based on the formula: $\mathrm{RPN}=\mathrm{S} \times \mathrm{O} \times \mathrm{D}$. High RPN values indicate a high level of risk and a high priority for precautions and improvements [30].

Currently, no data have discussed case studies on tire companies in the Tire static balance levels field. Authors try to fill the blanks by providing exposure to root cause analysis research using Fault Tree Analysis as root cause identification and Failure mode effect analysis as tools to determine the priority level of improvement. The results of this study can provide an overview of the problem-solving process by using FTA and FMEA in the field of Tire static balance levels in 
tire companies in Indonesia.

\section{RESEARCH METHODS}

The methodology used in this study started from a literature review related to problem-solving analysis activities through RCA, FTA, FMEA approaches. Root Cause analysis is carried out in stages [7];

1. Determining the problem and its specific symptoms, the identification stage of this issue is crucial to provide information and a clear picture of what problems and symptoms occur as the basis for conducting an analysis.

2. Collect data and information about the problem that occurred, the frequency of events, and how the impact carried out thorough investigation and analysis of the problem. For problemcausing analysis activities to run effectively, engaging people who truly understand the process has insight and experience in overcoming the problem. It is easier for us to understand the problems that occur to make fixes quickly.

3. Identify the possible causes, sequences of events, and conditions that lead to problems. This step is very important to identify as many potential factors as possible the cause of the problem to be done an in-depth analysis and then identify the Root Cause of the problem that has been identified in the previous step later. Possible causes that have been determined are explored in more detail and detail. In this case, focus group discussions can identify and determine the root of the problem.

4. Fix the problem by applying the solution that has been obtained from the root of the problem. It has been set in the previous step. This fix's results are standardized complete with preventive measures and documented to avoid the same problem in the future.

5. Evaluation to check the effectiveness obtained result towards the target.

To strengthen the root cause analysis, FTA is used for a more detailed analysis. The root cause of the problem found based on the analysis using FTA is entered into the potential failure cause in the FMEA table. Finally, risk assessment analysis is done by using FMEA to determine the recommended action.

\section{RESULTS AND DISCUSSION}

This research was conducted in one of the tire manufacturers in Indonesia. Tire defect problems were found caused by the static balance out the standard that impacts the amount of scrap and some delivery problems. As countermeasure action, problem-solving steps have been taken using RCA, FTA, and FMEA method.

\subsection{Define the problem \& Data collection}

One of the inspection parameters at the tire factory is the static balance. This parameter is checked regularly in the inspection section to ensure conformity to the tire specifications. Based on the inspection data report, from January until April 2020, the tire static balance out standard does not achieve the target and tends to increase in the last two months (Fig.1).

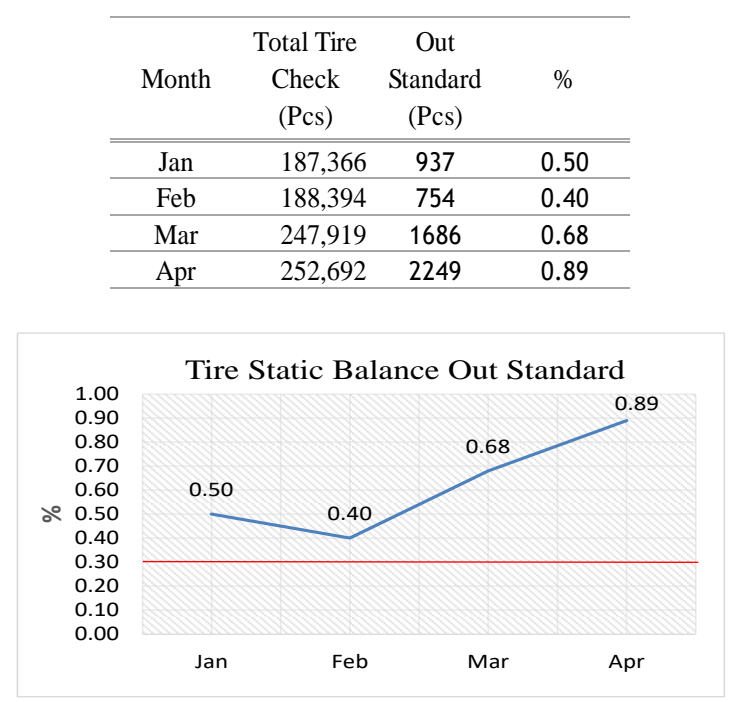

Fig.1. Tire static balance graph

\subsection{Identify Possible Causes}

To identify the possible cause was conducted using balance simulation level, measuring material length: divide and cut the material into eight slices (index), weigh material, calculate material weight, and convert into balance simulation level. Based on material weight simulation, the highest value for static balance level was breaker (Fig. 2)

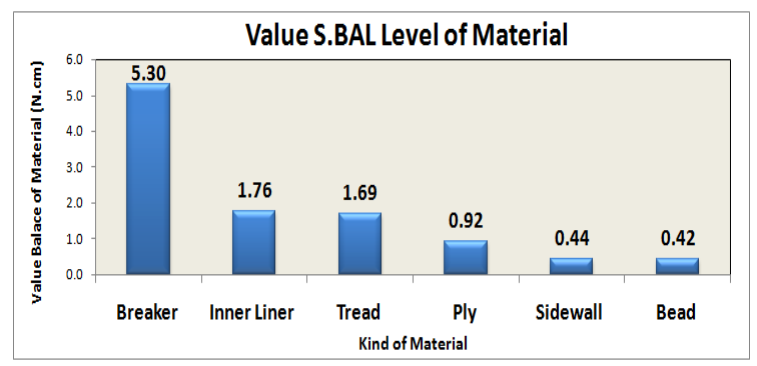

Fig. 2. Balance stimulation level 
Steel breaker is a part of the thread layer made of braided steel wire and placed between the tread and carcass/casing to strengthen the bond strength of both (Fig. 3). A Steel breaker's function is to protect and reduce the Tread's impact so that Carcass does not directly absorb it, support the vehicle weight, transmitting traction/braking power, and steering the vehicle direction. Steel breakers make from a rubber compound that has been transformed into rubber film in the insulation process and steel wire in the steel topped process (Fig. 4).

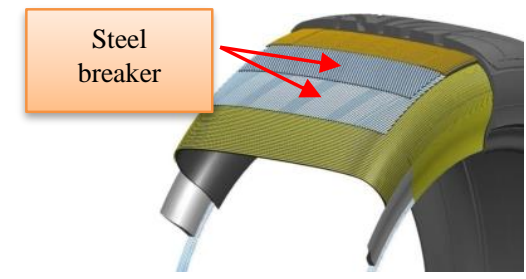

Fig. 3. Tire construction

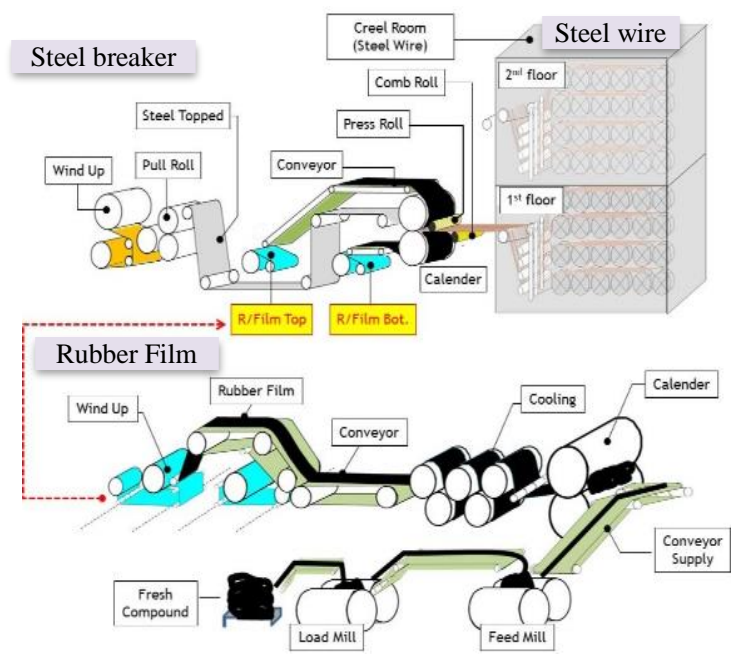

Fig. 4. Production process of steel breaker

The critical item in the two processes is the thickness of the material. The level of stability during the production process and material variation factors can cause the condition to be unstable and controlled periodically. Some material samples were taken to determine thickness variations (Fig. 5).

Based on the measurement data, the average Cpk value of the five samples analyzed is 0.83 . Cpk value $<1$ means that the process cannot indicate a problem in the previous process. Based on the steel breaker manufacturing process's production flow, the possible problem is the thickness variation in the rubber film before the joint with the steel wire. Then, measurements of the rubber film were carried out with a total of 13 sample pieces, which were taken in a width and length direction (Fig. 6).

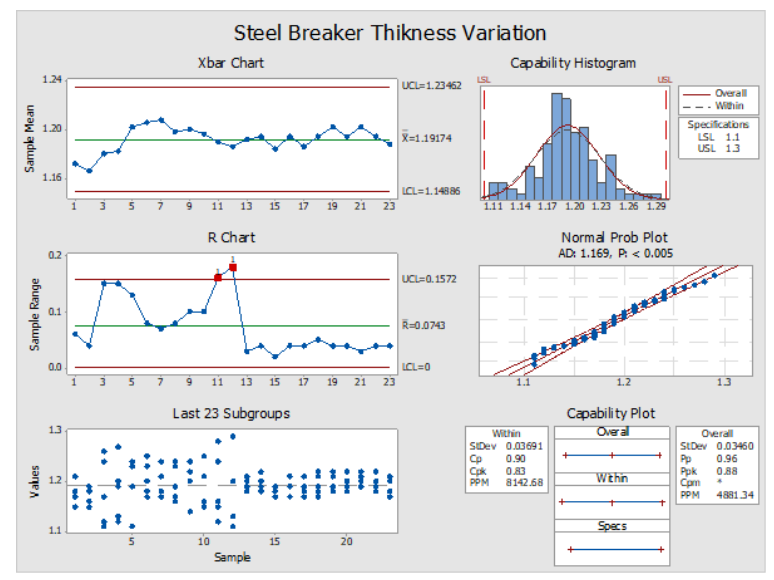

Fig. 5. Steel breaker thickness variation

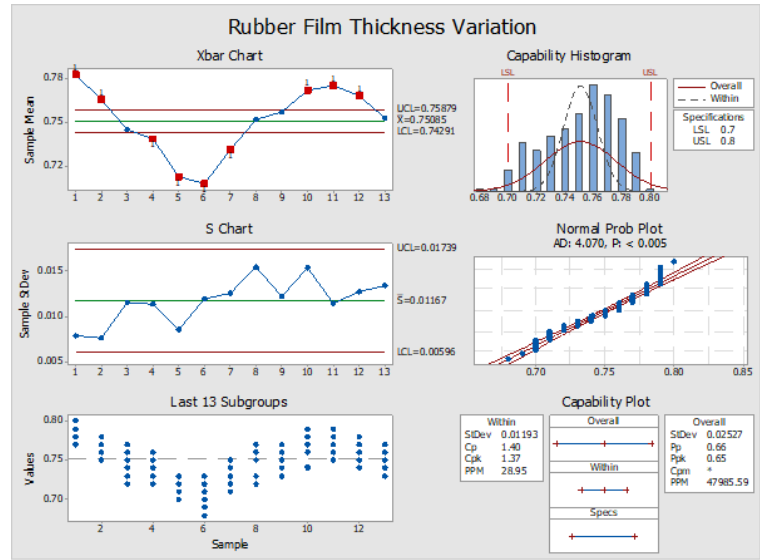

Fig. 6. Rubber film thickness variation

The thickness measurements were carried out on rubber film samples shows that there is a large thickness variation. Ppk value of 0.65 means the process is not capable. This condition directly identifies a correlation between the occurrence of variations in the steel breaker material caused by variations in rubber film as one of the materials used in the production process. The improvement in variations in the rubber film material will have a direct positive impact on the steel breaker material variations

\subsection{Identify Root Causes}

At this stage, an analysis process was carried out on all factors that influence the rubber film thickness occurrence to find the root cause of the problem. The analysis method uses FTA to find the root cause of each of the potential events that can cause process failure (Fig. 7). 


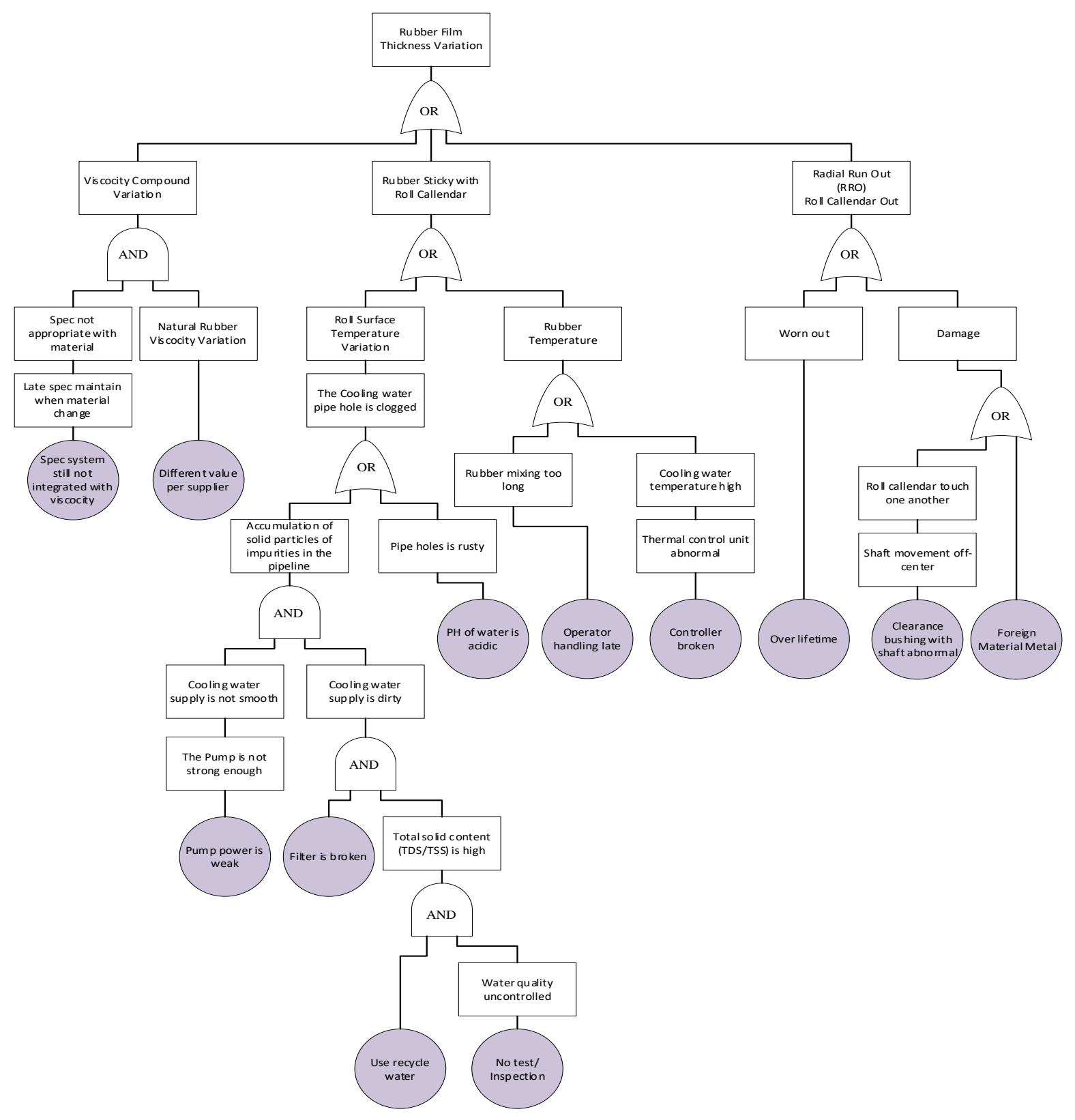

Fig. 7. Fault tree analysis

Based on the results of the analysis and direct checking on the production line, it was found that the dominant symptoms of the problems that have an impact on variations in the thickness are rubber sticky with roll calendar, Radial Run Out (RRO) calendar out standard and viscosity compound variation. The sticky problem is influenced by large variation temperatures on the calendar surface. This condition occurs due to a clogged in several cooling water pipe holes (Fig. 8), which impacts cooling water circulation, which is not smooth, causing the surface temperature to be unstable.

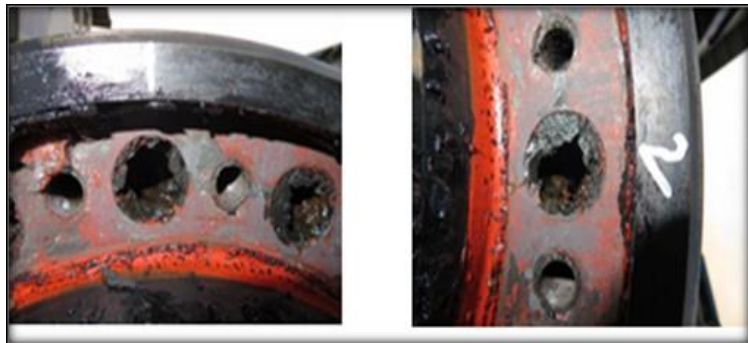

Fig. 8. Cooling water pipe hole

Another parameter problematic is RRO roll calendar no. 2 out standard (Fig. 9) Indicates a problem in the roundness concision roll calendar, 
which is affected by variations in radius of a radius of the center roll during silence and variations in the calendar shaft position at the time of spinning. For RRO checking, the gauge dial is affixed to the calendar surface and then roll rotated at a speed of 5 meters/minute by ten laps and is searched for variations in each predetermined position.

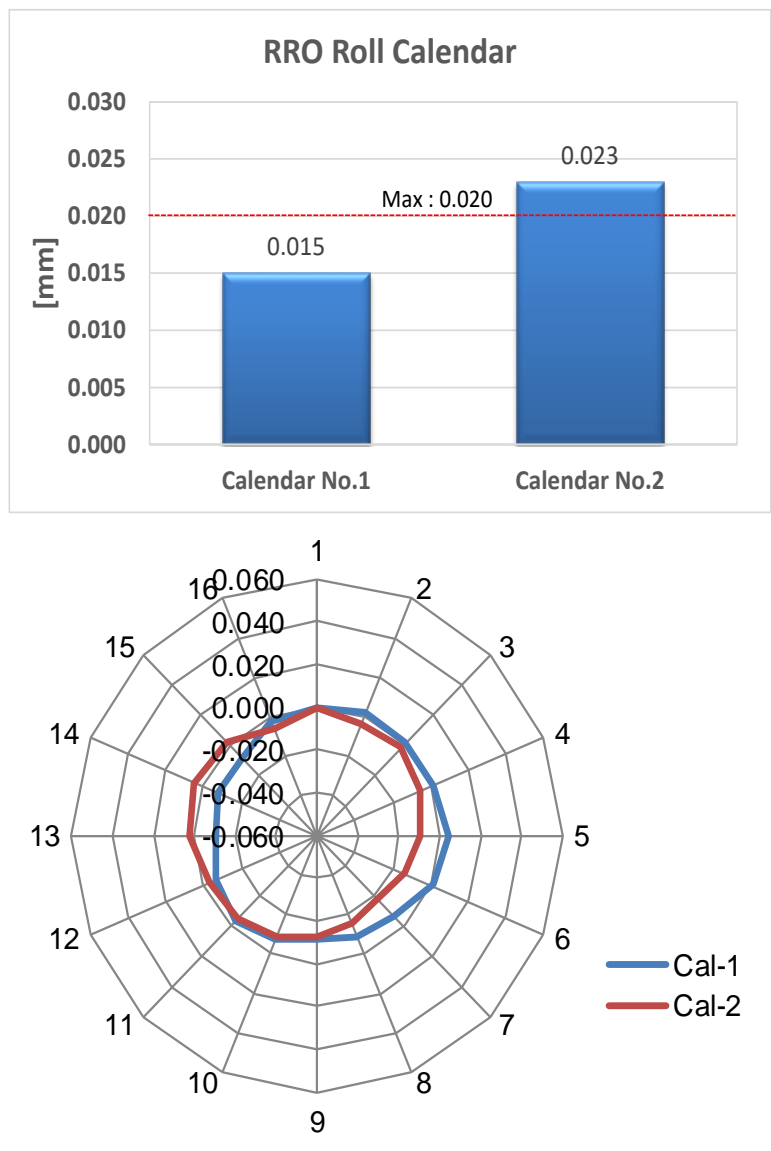

Fig. 9. RRO roll calendar

The next problem was the condition of the viscosity variation in the compound used for the manufacture of rubber film where this viscosity value would impact the rubber flow, which could also affect the rubber film thickness variation. The viscosity compound data obtained from the testing laboratory (Fig. 10) shows the large variation conditions that need to be fixed.

The material used for compound making consists of $100 \%$ of natural rubber and other constituent materials. It is currently using more than ten suppliers with different characteristics of viscosity values. Difficulties generally cause variations during the maintenance spec, so it is necessary to repair the system and poka-yoke to overcome this problem. Overall, based on an analysis using FTA, the cause of rubber sticky with roll calendar, RRO out standard, and viscosity compound variation found 12 root problems that must be fixed to avoid the same problem occurring in the future.

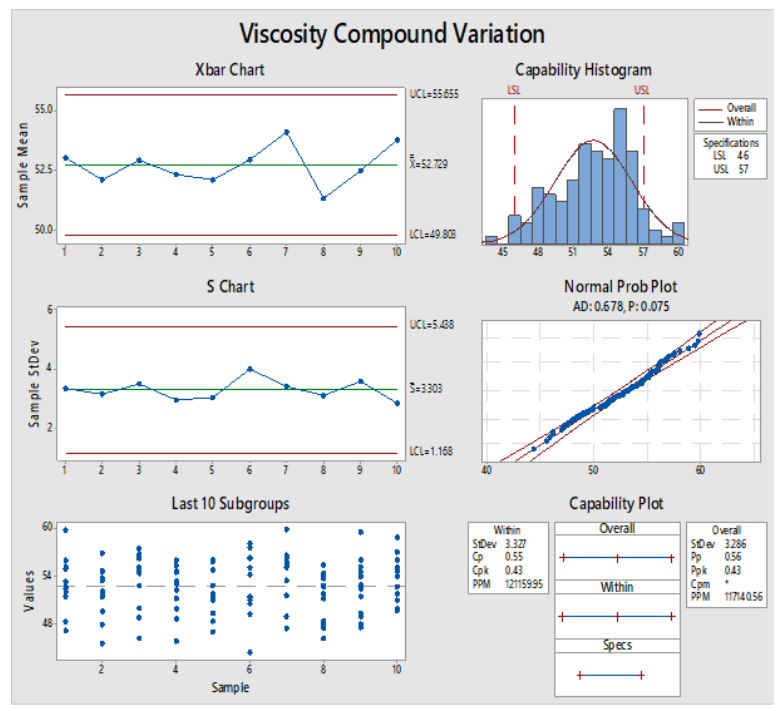

Fig. 10. Data viscosity compound

\subsection{Fix the problem}

At this stage, analysis and problem-solving steps are carried out using the FMEA core tool to define corrective and preventive action and then minimize failure factors. The root cause is the failure cause in the FMEA and then calculates the risk priority number (RPN) based on the multiplication of the value of severity, occurrence, and detection. RPN value is set by the company $<100$ as an internal standard to prevent the failure factor. The recommended action should be made to reduce the frequency of occurrence and improve the detection system (Table 1).

Based on the process assessment results through the FMEA approach, we can see that the improvement can effectively reduce RPN $<100$ as the company target by decreasing the frequency problem/occurrence and an increase in detection systems. It shows that the potential risk of process failure in all factors that can cause defects can be reduced with a lower risk of failure. With these conditions, it is hoped that it can effectively reduce the defect problems that are currently being faced. 
Table 1. FMEA table

\begin{tabular}{|c|c|c|c|c|c|c|c|c|c|c|c|c|c|}
\hline \multirow{2}{*}{$\begin{array}{l}\text { Potential } \\
\text { Failure } \\
\text { Mode }\end{array}$} & \multirow{2}{*}{$\begin{array}{c}\text { Potential } \\
\text { effect (s) } \\
\text { of failure }\end{array}$} & \multirow{2}{*}{$\begin{array}{l}\text { Potential } \\
\text { cause(s) of } \\
\text { failure }\end{array}$} & \multirow{2}{*}{$\begin{array}{l}\text { Cause } \\
\text { Factor }\end{array}$} & \multicolumn{3}{|c|}{ Current Process } & \multirow[b]{2}{*}{ RPN } & \multicolumn{2}{|c|}{ Recommended Action } & \multicolumn{3}{|c|}{ After Improve } & \multirow[b]{2}{*}{ RPN } \\
\hline & & & & Sev & Occ & Det & & $\begin{array}{c}\text { Controls } \\
\text { Prevention }\end{array}$ & $\begin{array}{c}\text { Control } \\
\text { Detection }\end{array}$ & Sev & Occ & Det & \\
\hline \multirow[t]{7}{*}{$\begin{array}{l}\text { Rubber } \\
\text { Sticky } \\
\text { with roll } \\
\text { calendar }\end{array}$} & \multirow[t]{7}{*}{$\begin{array}{l}\text { Rubber } \\
\text { film } \\
\text { thickness } \\
\text { variation }\end{array}$} & $\begin{array}{l}\text { Less } \\
\text { powerful } \\
\text { circulation } \\
\text { water pump }\end{array}$ & Machine & 8 & 3 & 8 & 192 & $\begin{array}{l}\text { Pump motor } \\
\text { change from } \\
1.7 \mathrm{KW} \text { to } 3.5 \\
\mathrm{KW}\end{array}$ & $\begin{array}{l}\text { Pressure } \\
\text { gauge }\end{array}$ & 8 & 1 & 8 & 64 \\
\hline & & $\begin{array}{l}\text { Controller } \\
\text { thermal } \\
\text { unit broken }\end{array}$ & Machine & 8 & 3 & 8 & 192 & $\begin{array}{l}\text { Periodical } \\
\text { check } \\
1 \mathrm{x} / \text { moth }\end{array}$ & $\begin{array}{l}\text { Check } \\
\text { sheet } \\
\text { control }\end{array}$ & 8 & 1 & 5 & 40 \\
\hline & & $\begin{array}{l}\text { Cooling } \\
\text { water filter } \\
\text { damage }\end{array}$ & Machine & 8 & 3 & 8 & 192 & $\begin{array}{l}\text { Periodical } \\
\text { check } \\
1 \mathrm{x} / \text { moth }\end{array}$ & $\begin{array}{l}\text { Check } \\
\text { sheet } \\
\text { control }\end{array}$ & 8 & 1 & 5 & 40 \\
\hline & & $\begin{array}{l}\text { Use recycle } \\
\text { water }\end{array}$ & Material & 8 & 3 & 10 & 240 & $\begin{array}{l}\text { Change type } \\
\text { of water with } \\
\text { Reverse } \\
\text { Osmosis with } \\
\text { PH value } 8.5\end{array}$ & $\begin{array}{l}\text { Check } \\
\text { sheet } \\
\text { inspection } \\
\text { record }\end{array}$ & 8 & 1 & 5 & 40 \\
\hline & & $\begin{array}{l}\text { Acidic } \\
\text { water } \\
(\mathrm{PH}<7)\end{array}$ & Material & 8 & 3 & 10 & 240 & $\begin{array}{l}\text { Change type } \\
\text { of water with } \\
\text { Reverse } \\
\text { Osmosis with } \\
\text { PH value } 8.5\end{array}$ & $\begin{array}{l}\text { Check } \\
\text { sheet } \\
\text { inspection } \\
\text { record }\end{array}$ & 8 & 1 & 5 & 40 \\
\hline & & $\begin{array}{l}\text { There is no } \\
\text { inspection } \\
\text { of cooling } \\
\text { water } \\
\text { quality }\end{array}$ & Method & 8 & 3 & 10 & 240 & $\begin{array}{l}\text { Periodical } \\
\text { check when } \\
\text { adjustment of } \\
\text { water level }\end{array}$ & $\begin{array}{l}\text { Check } \\
\text { sheet } \\
\text { inspection } \\
\text { record }\end{array}$ & 8 & 1 & 5 & 40 \\
\hline & & $\begin{array}{l}\text { Late } \\
\text { handling } \\
\text { Operator }\end{array}$ & Man & 8 & 1 & 5 & 40 & $\begin{array}{l}\text { Periodical } \\
\text { training }\end{array}$ & $\begin{array}{l}\text { Competenc } \\
\text { y skill } \\
\text { matrix skill }\end{array}$ & 8 & 1 & 4 & 32 \\
\hline $\begin{array}{l}\text { RRO Roll } \\
\text { Calendar } \\
\text { out }\end{array}$ & & $\begin{array}{l}\text { Over } \\
\text { Lifetime }\end{array}$ & Machine & 8 & 1 & 8 & 64 & $\begin{array}{l}\text { Periodical } \\
\text { control and } \\
\text { change }\end{array}$ & $\begin{array}{l}\text { Check } \\
\text { sheet } \\
\text { control }\end{array}$ & 8 & 1 & 5 & 40 \\
\hline standard & & $\begin{array}{l}\text { Clearance } \\
\text { Bushing } \\
\text { with shaft } \\
\text { abnormal }\end{array}$ & Machine & 8 & 3 & 10 & 240 & $\begin{array}{l}\text { Periodical } \\
\text { check } \\
1 \mathrm{x} / \text { moth }\end{array}$ & $\begin{array}{l}\text { Check } \\
\text { sheet } \\
\text { control }\end{array}$ & 8 & 1 & 5 & 40 \\
\hline & & $\begin{array}{l}\text { Foreign } \\
\text { material } \\
\text { metal }\end{array}$ & Material & 8 & 5 & 1 & 40 & $\begin{array}{l}\text { Periodical } \\
\text { check metal } \\
\text { detector } \\
1 \mathrm{x} / \text { shift }\end{array}$ & $\begin{array}{l}\text { Pokayoke } \\
\text { metal } \\
\text { detector }\end{array}$ & 8 & 1 & 1 & 8 \\
\hline \multirow[t]{2}{*}{$\begin{array}{l}\text { Viscosity } \\
\text { Compound } \\
\text { Variation }\end{array}$} & & $\begin{array}{l}\text { Natural } \\
\text { Rubber } \\
\text { supplier } \\
\text { viscosity } \\
\text { variation }\end{array}$ & Material & 8 & 5 & 6 & 240 & $\begin{array}{l}\text { Integrated } \\
\text { data material } \\
\text { viscosity with } \\
\text { spec system }\end{array}$ & Poka-yoke & 8 & 3 & 1 & 24 \\
\hline & & $\begin{array}{l}\text { Spec } \\
\text { system still } \\
\text { not } \\
\text { integrated } \\
\text { with } \\
\text { viscosity } \\
\text { material }\end{array}$ & Method & 8 & 5 & 6 & 240 & $\begin{array}{l}\text { Integrated } \\
\text { data material } \\
\text { viscosity with } \\
\text { spec system }\end{array}$ & Poka-yoke & 8 & 3 & 1 & 24 \\
\hline
\end{tabular}

\subsection{Evaluation}

At this stage, an evaluation is carried out to see its effect on the results of the improvements that have been made to the problems that cause defects, especially the material thickness variation on the rubber film (Fig. 11) and the steel breaker material (Fig. 12). The capability process of rubber film thickness variation was increased with the value of $\mathrm{Cp}=2.06, \mathrm{Cpk}=1.71 \mathrm{Pp}=1.39 \mathrm{Ppk}$ $=1.18$
Improving variations in the rubber film material will directly impact increasing the variation of the steel breaker material (Fig. 12). The capability process was increased with the value of $\mathrm{Cp}=2.06$, $\mathrm{Cpk}=1.91 \mathrm{Pp}=2.15 \mathrm{Ppk}=1.99$. Both results show that the process is perfect; almost all data is included in the specification limit. The improvements are seen in a reduction in the number of defects tire static balance out the standard by $54.65 \%$ (Fig. 13). 


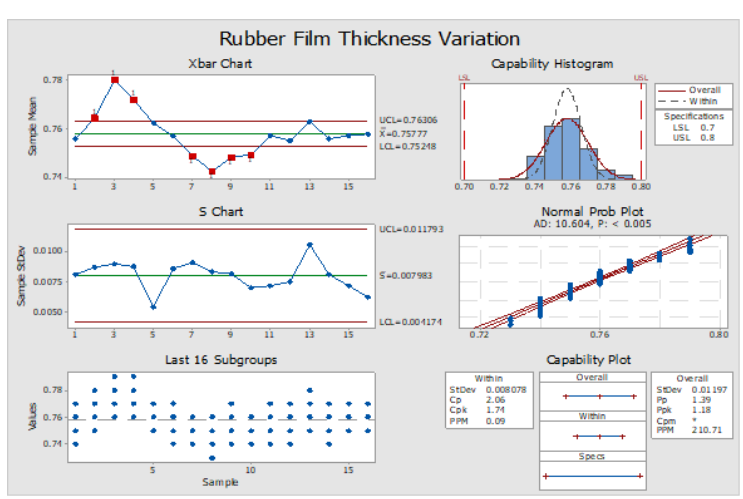

Figure 11. Rubber film thickness variation

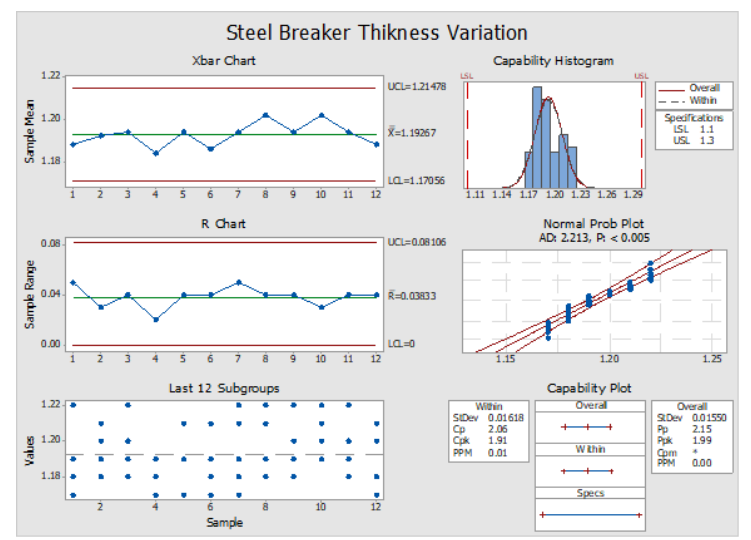

Fig. 12. Steel breaker thickness variation

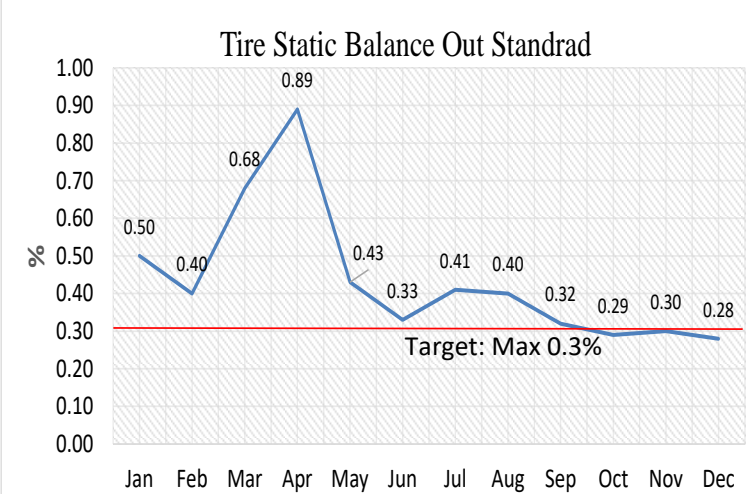

Fig. 13. Tire static balance graph

Thus, the problem-solving methods and improvement activities that have been carried out can effectively achieve targets. Previous researchers have carried out a methodological problem-solving method by combining FMEA and FTA for internal risk assessment in the production process [4] and risk analysis for preventing underwater explosions [11]. The implementation of this method is able to improve delivery performance in terms of the average total time reduced by $29.39 \%$ [18]. In this research, the methodology is applied in the tire manufacturing industry. The results effectively reduce the defect ratio due to static balance out the standard by $54.65 \%$.

\section{CONCLUSION}

A problem-solving step analysis was carried out. These methods can help find the root cause of the problem and determine the recommended actions as corrective and preventive action. The improvements that have been done can effectively improve the capability process on rubber film and steel breaker materials that impact decreasing defect tire static balance out. In future research, lean kaizen and poka-yoke can be considered to maintain detection systems and increase quality.

\section{ACKNOWLEDGMENT}

The author would like to express deepest gratitude and appreciation to all parties who have helped during this research, including the editors and reviewers.

\section{REFERENCES}

[1] E. W. Yunitasari, R. Widiastuti, B. S. Wisnuaji, M. Erwinda, and E. Sutanta, "Analysis of the quality of wheel chain products at UPT logam Yogyakarta using FMEA method," J. Phys. Conf. Ser., vol. 1456, p. 12033, 2020, doi: 10.1088/17426596/1456/1/012033.

[2] S. Karabay and I. Uzman, "Importance of early detection of maintenance problems in rotating machines in management of plants: Case studies from wire and tyre plants," Eng. Fail. Anal., vol. 16, no. 1, pp. 212-224, 2009, doi: 10.1016/j.engfailanal.2008.03.003.

[3] N. Dhanrale, B. Aldar, S. Bhatambrekar, and P. Pardeshi, "Reduction of wheel unbalance during design \& manufacturing by reducing process variation," in nternational Engineering Research Journal, 2015, pp. 159-164. Available: http://www.ierjournal.org/pupload/mitpgc on/MD1-46.pdf.

[4] N. A. Wessiani and F. Yoshio, "Failure mode effect analysis and fault tree analysis as a combined methodology in risk management," IOP Conf. Ser. Mater. Sci. Eng., vol. 337, p. 12033, 2018, doi: 10.1088/1757-899x/337/1/012033.

[5] D. Safira, F. Safitri, H. Kamal, Meilani, C. M. Sujana, and A. Andika, "Time 
accelaration of offshore EPC project using FMEA, FTA, CPM and crashing method at PT XYZ," IOP Conf. Ser. Earth Environ. Sci., vol. 426, p. 12126, 2020, doi: 10.1088/1755-1315/426/1/012126.

[6] M. Cheshmberah, A. Naderizadeh, A. Shafaghat, and M. Karimi Nokabadi, "An integrated process model for root cause failure analysis based on reality charting, FMEA and DEMATEL," Int. J. Data Netw. Sci., vol. 4, no. 2, pp. 225-236, 2020, doi: $10.5267 / j . i j d n s .2019 .12 .003$.

[7] V. Goa, "General model for RCA in Manufacturing Industry. Case study from Kverneland Group," University of Stavanger, Norway, 2017. Available: https://uis.brage.unit.no/uisxmlui/handle/11250/2460093.

[8] A. A. Utami and N. W. P. Susatyo, "Aplikasi Fault Tree Analysis Perbedaan Persepsi Campus Sustainability Mahasiswa dalam Perilaku Pro Lingkungan Dilingkungan Kampus," Oper. Excell., vol. 10, no. 1, pp. 101-106, 2018. Available: https://publikasi.mercubuana.ac.id/index.p hp/oe/article/view/3824.

[9] R. K. Sharma and P. Sharma, "Qualitative and quantitative approaches to analyse reliability of a mechatronic system: a case," J. Ind. Eng. Int., vol. 11, no. 2, pp. 253-268, 2015, doi: 10.1007/s40092-0150098-6.

[10] J.-H. Lee, S. Hwang, and S. Kim, "Safety Assessment of LNG Transferring System subjected to gas leakage using FMEA and FTA," J. Adv. Res. Ocean Eng., vol. 3, no. 3, pp. 125-135, 2017, doi: 10.5574/JAROE.2017.3.3.125.

[11] M. Shafiee, E. Enjema, and A. Kolios, "An Integrated FTA-FMEA Model for Risk Analysis of Engineering Systems: A Case Study of Subsea Blowout Preventers," Applied Sciences, vol. 9, no. 6. p. 1192, 2019, doi: 10.3390/app9061192.

[12] I. Alqais and Erryrimawan, "Reducing Main Engine Failure using the FMEA Method in LPG Refineries," Int. J. Mech. Prod. Eng. Res. Dev. (IJMPERD ), vol. 9, no. 6, pp. 873-886, 2019. Available: http://www.tjprc.org/view_paper.php?id= 12195.

[13] A. L. Ungureanu and G. Stan, "Improving
FMEA risk assessment through reprioritization of failures," IOP Conf. Ser. Mater. Sci. Eng., vol. 145, p. 22004, 2016, doi: 10.1088/1757-899x/145/2/022004.

[14] S. Supriyati and H. Hasbullah, "Analisis cacat painting komponen automotive dengan pendekatan DMAIC-FMEA," Oper. Excell. J. Appl. Ind. Eng., vol. 12, no. 1, pp. 104-116, Mar. 2020, doi: 10.22441/oe.2020.v12.i1.009.

[15] J. F. W. Peeters, R. J. I. Basten, and T. Tinga, "Improving failure analysis efficiency by combining FTA and FMEA in a recursive manner," Reliab. Eng. Syst. Saf., vol. 172, pp. 36-44, 2018, doi: 10.1016/j.ress.2017.11.024.

[16] N. G. Mutlu and S. Altuntas, "Risk analysis for occupational safety and health in the textile industry: Integration of FMEA, FTA, and BIFPET methods," Int. J. Ind. Ergon., vol. 72, pp. 222-240, 2019, doi: 10.1016/j.ergon.2019.05.013.

[17] M. Vodenicharova, "Opportunities for the applications of FMEA Model in logistics processes in Bulgarian enterprises," Logist. Sustain. Transp., vol. 8, no. 1, pp. 31-41, May 2017, doi: 10.1515/jlst-20170003.

[18] R. Hutabarat, T. H. Sen Rimo, Meilani, and A. Andika, "Improving delivery performance by using simulation, FMEA, and FTA," IOP Conf. Ser. Earth Environ. Sci., vol. 426, p. 12125, 2020, doi: 10.1088/1755-1315/426/1/012125.

[19] N. G. Mutlu and S. Altuntas, "Hazard and risk analysis for ring spinning yarn production process by integrated fta-fmea approach," Tekst. ve Konfeksiyon, vol. 29, no. 3, pp. 208-218, Sep. 2019, doi: 10.32710/tekstilvekonfeksiyon.482167.

[20] E. Ruijters and M. Stoelinga, "Fault tree analysis: A survey of the state-of-the-art in modeling, analysis and tools," Comput. Sci. Rev., vol. 15-16, pp. 29-62, 2015, doi: 10.1016/j.cosrev.2015.03.001.

[21] I. Tubert-Brohman, W. Sherman, M. Repasky, and T. Beuming, "Improved Docking of Polypeptides with Glide," $J$. Chem. Inf. Model., vol. 53, no. 7, pp. 1689 1699, Jul. 2013, doi: 10.1021/ci400128m.

[22] M. Kirchhof, K. Haas, T. Kornas, S. Thiede, M. Hirz, and C. Herrmann, "Root Cause Analysis in Lithium-Ion Battery 
Production with FMEA-Based LargeScale Bayesian Network," CIRP J. Manuf. Sci. Technol., pp. 1-19, 2020, doi: 10.20944/preprints202012.0312.v1.

[23] K. P. Kour, L. Talwar, and N. S. Bhangu, "Wind Turbine Reliability Analysis In Case of Wind Turbine Blades," Int. J. Innov. Res. Sci. Eng. Technol., vol. 8, no. 10, pp. 9922-9929, 2019. Available: https://www.ijirset.com/upload/2019/octo ber/5_Wind.PDF.

[24] T. Aized, M. Ahmad, M. H. Jamal, A. Mahmood, S. Ubaid ur Rehman, and J. S. Srai, "Automotive leaf spring design and manufacturing process improvement using failure mode and effects analysis (FMEA)," Int. J. Eng. Bus. Manag., vol. 12, p. 1847979020942438, Jan. 2020, doi: 10.1177/1847979020942438.

[25] A. R. Aprilia, I. Santoso, and D. M. Ekasari, "The integration methods of fuzzy fault mode and effect analysis and fault tree analysis for risk analysis of yogurt production," AIP Conf. Proc., vol. 1844, no. 1, p. 30008, May 2017, doi: 10.1063/1.4983435.

[26] R. A. K. W. Campus and R. Al Khaimah, "Software Failure Analysis using FMEA," Int. J. Softw. Eng. Its Appl., vol. 12, no. 3, pp. 19-28, 2018. Available:
https://gvpress.com/journals/IJSEIA/vol1 2_no3/2.pdf.

[27] K. Shanks, A. Hamad, and A. Ameer, "Failure Modes Effects and Criticality Analysis and Fault Tree Analysis Case Study of Waste Heat Recovery Plant in a Cement Factory, United Arab Emirates," $J$. Fail. Anal. Prev., vol. 20, no. 1, pp. 40-50, 2020, doi: 10.1007/s11668-020-00827-8.

[28] D. H. Stamatis, The ASQ pocket guide to failure mode and effect analysis (FMEA). Quality Press, 2014. Available: https://asq.org/quality-press/displayitem?item $=$ E1468.

[29] H. M. Kwon, S. H. Hong, and M. K. Lee, "A Risk Metric for Failure Cause in FMEA under Time-Dependent Failure Occurrence and Detection," J. Korean Soc. Qual. Manag., vol. 47, no. 3, pp. 571-582, 2019, $\quad$ doi: 10.7469/JKSQM.2019.47.3.571.

[30] T. M. El-Dogdog, A. M. El-Assal, I. H. Abdel-Aziz, and A. A. El-Betar, "Implementation of FMECA and Fishbone Techniques in Reliability Centered Maintenance Planning," Int. J. Innov. Res. Sci. Eng. Technol., vol. 5, no. 11, pp. 18801-18811.

Available: https://www.ijirset.com/upload/2016/nove mber/1A_Implementation.pdf. 